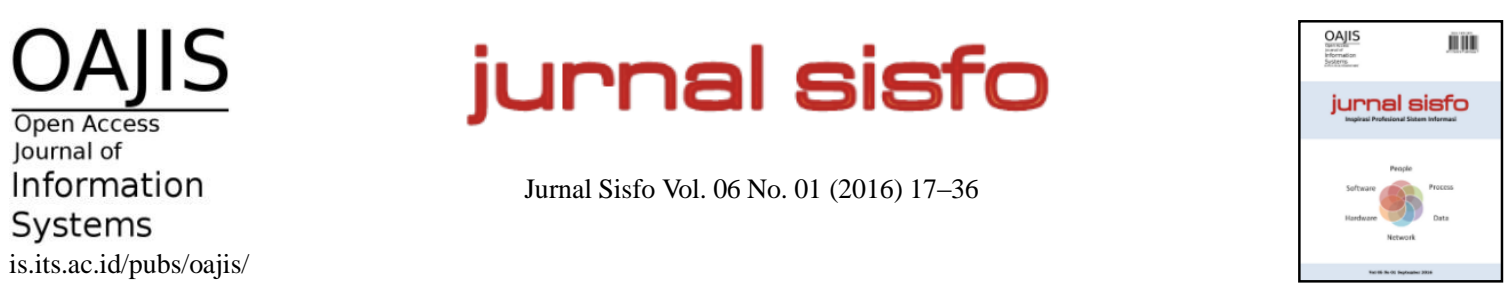

\title{
Identifikasi Jenis Obat Berdasarkan Gambar Logo Pada Kemasan Menggunakan Metode Naive Bayes
}

\author{
I Gede Surya Rahayuda* \\ Sistem Informasi, STMIK STIKOM Bali
}

\begin{abstract}
Many people consume drugs to maintain health, prevent disease or cure. These types of drugs have been defined both nationally and internationally, generally these types of drugs written in the form of logo on the packaging of drugs. There are so many types of medications that have been approved by the government and has been circulating in the community, in this study I use 4 different types of modern medicine and three kinds of herbal medicine, in total there will be as many as 7 different logo that will be used. In this research, will be created an application that can identify the type of drugs based logos contained on the packaging. To identify them, can be done by taking pictures logo on the packaging of the drug. Then the image is stored and then processed by an application that has been made, the application will provide information such as the type of drug. Application will be made using MATLAB and the methods used for image classification is Naive Bayes.
\end{abstract}

Keywords: Medicine Logo, Image Processing, Edge detection, GLCM, Nave Bayes

\begin{abstract}
Abstrak
Banyak masyarakat yang sering mengkonsumsi obat untuk menjaga kesehatan, mencegah penyakit maupun menyembuhkan sakit. Jenis obat sudah ditetapkan baik secara nasional maupun international, umumnya jenis obat ini dituliskan berupa logo pada kemasan obat. Terdapat sangat banyak jenis obat yang telah disetujui oleh pemerintah dan telah beredar di masyarakat, pada penelitian ini saya menggunakan 4 jenis obat modern dan 3 jenis obat herbal, total akan terdapat sebanyak 7 macam logo yang akan digunakan. Dalam penelitian ini saya ingin membuat suatu aplikasi yang dapat mengindentifikasi jenis obat berdasarkan logo yang terdapat pada kemasan. Untuk mengidentifikasinya, dapat dilakukan dengan cara memfoto logo pada kemasan obat. Kemudian gambar disimpan dan kemudian diproses oleh aplikasi yang telah dibuat, aplikasi akan memberikan informasi berupa jenis obat. Aplikasi akan dibuat menggunakan MATLAB dan metode yang digunakan untuk klasifikasi gambar adalah Naive Bayes.
\end{abstract}

Kata kunci: Logo obat, Pemrosesan gambar, Deteksi tepi, GLCM, Nave Bayes

() 2016 Jurnal SISFO

Histori Artikel: Disubmit 16 Mei 2016; Diterima 13 Juli 2016; Tersedia online 11 Agustus 2016

\footnotetext{
* Corresponding Author

Email address: surya.rahayuda@gmail.com (I Gede Surya Rahayuda)
} 


\section{Pendahuluan}

Obat merupakan suatu benda atau zat yang dapat digunakan untuk menjaga kesehatan, mencegah penyakit, dan juga untuk menyembuhkan sakit. Hampir semua orang pernah mengkonsumsi obat, saat ini obat banyak ditemukan atau dijual di apotik dan juga di warung atau di toko. Namun tidak semua orang mengetahui bahwa obat memiliki jenis atau katagori yang sebaiknya diketahui oleh masyarakat. Jenis obat telah ditetapkan baik secara nasional maupun internasional [1] [2]. Terdapat berbagai macam jenis logo obat. Obat dikategorikan menjadi beberapa jenis seperti, obat bebas, obat terbatas, obat keras, obat herbal, obat tradisional, obat bius atau narkotika dan lainnya [3] [4]. Logo jenis obat tersebut umumnya terdapat pada bagian kemasan obat, logo obat umunya beberntuk seperti lingkaran dengan warna hijau atau biru, lingkaran dengan huruf $\mathrm{K}$, lingkaran dengan tanda positif, lingkaran dengan gambar daun dan masih banyak bentuk logo lainnya.

Masyarakat pada umumnya tidak terlalu memperhatikan logo tersebut sebelum mengkonsumsinya. Tentunya hal ini akan dapat berdampak tidak baik bagi kesehatan pengguna jika seandainya obat tersebut tergolong kedalam jenis obat yang memerlukan resep dari dokter atau merupakan jenis obat keras [5]. Hal ini akan dapat menyebabkan efek samping yang merugikan kesehatan.

Berdasarkan beberapa pemikiran tersebut maka penulis merasa perlu untuk melakukan sebuah penelitian dan menggunakan teknologi informasi untuk dapat memberikan informasi dan memudahkan masyarakat dalam mengidentifikasi jenis obat melalui logo yang terdapat dalam kemasan. Penelitian ini dilakukan dengan mengambil beberapa sample dengan cara mengambil gambar logo obat pada kemasan menggunakan camera poket atau kamera handphone. Kemudian membuat suatu aplikasi menggunakan MATLAB Programming, dimana nantinya gambar logo tersebut akan diproses menggunakan beberapa metode seperti: RGB to Grey, Edge Detection, dan GLCM. Metode tersebut digunakan agar gambar dapat diubah menjadi data seperti angka yang nantinya akan memudahkan proses klasifikasi data. Proses klasifikasi data yang akan digunakan adalah Naive Bayes, alasan memilih untuk menggunakan metode ini karena metode ini mudah untuk dipahami, cepat dalam perhitungannya, hanya memerlukan pengkodean yang sederhana, hanya memerlukan sejumlah kecil data untuk mengestimasi parameter dan juga kokoh terhadap atribut yang tidak relevan [6].

\section{Tinjauan Pustaka}

\subsection{Edge Detection}

Untuk mendapatkan bentuk dari logo yang terdapat pada sebuah gambar, perlu dilakukan pendeteksian tepi dari gambar logo tersebut. Dimana sebelumnya telah dilakukan proses $R G B$ to Grey, karena hanya gambar yang berwarna abu atau tidak berwarna yang dapat dideteksi tepinya. Pendeteksian tepi dari sebuah gambar bisa dikatakan seperti membuat sketsa kasar dari sebuah objek, sehingga akan terlihat lebih jelas bentuk dari objek tersebut. Nantinya hanya akan terdapat 2 buah warna yaitu hitam dan putih, hitam sebagai latar gambar dan putih sebagai garis yang membentuk sebuah objek. Proses pendeteksian tepi ini dilakukan menggunakan metode Edge Detection.

Edge Detection adalah pendekatan yang paling umum digunakan untuk mendeteksi diskontinuitas Gray Level. Hal ini disebabkan karena titik ataupun garis yang terisolasi tidak terlalu sering dijumpai dalam aplikasi praktis. Secara ideal, teknik yang digunakan untuk mendeteksi diskontinuitas seharusnya hanya menghasilkan pixel yang berada pada batas region. Namun dalam prakteknya hal ini jarang terjadi karena adanya noise, batas yang terpisah karena pencahayaan yang tidak merata, dan efek lain yang mengakibatkan variasi intensitas [7]. Ada beberapa metode dalam Edge Detection [8] [9], seperti: metode Robert, metode Prewitt, metode Sobel, metode Canny, dan metode Laplacian Gaussian. Metode Edge Detection yang digunakan pada penelitian ini adalah metode Canny. 
Canny Edge Detector dikembangkan oleh John F. Canny pada tahun 1986 dan menggunakan algoritma multi tahap untuk mendeteksi berbagai tepi dalam gambar. Walaupun metode tersebut telah berumur cukup lama, namun metode tersebut telah menjadi metode deteksi tepi standar dan masih dipakai dalam penelitan[10]. Adapun kategori algoritma yang dikembangkan oleh John F. Canny adalah sebagai berikut:

1) Deteksi, kemungkinan mendeteksi titik tepi yang benar harus dimaksimalkan sementara kemungkinan salah mendeteksi titik tepi harus diminimalkan. Hal ini diamksudkan untuk memaksimalkan rasio signal to noise.

2) Lokalisasi, tepi terdeteksi harus sedekat mungkin dengan tepi yang nyata.

3) Jumlah tanggapan, satu tepi nyata tidak harus menghasilkan lebih dari satu ujung yang terdeteksi.

Dengan rumusan John F. Canny tentang kriteria ini, maka Canny Edge Detector optimal untuk kelas tepian tertentu yang dikenal sebagai step edge. Algoritma Canny berjalan dalam 5 langkah yang terpisah yaitu:

1) Smoothing, mengaburkan gambar untuk menghilangkan noise

2) Finding gradient, tepian harus ditandai pada gambar memiliki gradien yang besar.

3) Non maksimum suppression, hanya maxima lokal yang harus ditandai sebagai egde.

4) Double thresholding, tepian yang berpotensi ditentukan oleh thresholding.

5) Edge tracking by hysteresis, tepian final ditentukan dengan menekan semua sisi yang tidak terhubung

\subsection{GLCM}

Tekstur merupakan elemen penting dari persepsi visual yang dapat digunakan untuk memisahkan area yang menarik dari suatu gambar [11]. Tekstur dapat memuat informasi penting tentang struktur dan hubungannya dengan daerah sekitarnya. Arti dari tekstur adalah keteraturan pola tertentu yang terbentuk dari susunan piksel-piksel dalam citra digital [12], [13]. Salah satu bagian penting dari analisis tekstur adalah dengan menggunakan intensitas pasangan matriks (Grey Level Co-Ocurance Matrix atau GLCM) yang merupakan dua hubungan matriks dimensi [14]. Matriks adalah matriks pasangan intensitas yang menggambarkan frekuensi munculnya dua pasang piksel dengan intensitas tertentu dalam jarak dan arah tertentu pada gambar [15], [16]. GLCM dapat dihitung dengan menggunakan beberapa ruang diimbangi arah yang 0 derajat, 45 derajat, 90 derajat, dan 135 derajat. Dari matrik GLCM yang diperoleh, karakteristik tekstur citra yang digunakan dalam penelitian ini dapat diukur dengan menggunakan fitur seperti yang terlihat pada Tabel 1 .

Tabel 1. Deskripsi Komponen Segmentasi GLCM

\begin{tabular}{|c|c|}
\hline Nama & Deskripsi \\
\hline Contrast & $\begin{array}{l}\text { Digunakan untuk mengukur fluktuasi distribusi intensitas dengan menggunakan } \\
\text { persamaan } 1\end{array}$ \\
\hline Correlation & $\begin{array}{l}\text { Digunakan untuk mengukur korelasi antara piksel untuk piksel tetangga dari seluruh } \\
\text { gambar dengan menggunakan persamaan } 2\end{array}$ \\
\hline Homogeneity & $\begin{array}{l}\text { Homogenitas digunakan untuk mengukur variasi intensitas gambar dengan } \\
\text { menggunakan persamaan } 3\end{array}$ \\
\hline Energy & $\begin{array}{l}\text { Digunakan untuk mengukur konsentrasi intensitas pasangan di cooccurrence matriks } \\
\text { menggunakan persamaan } 4\end{array}$ \\
\hline
\end{tabular}

Tabel 2 merupakan persamaan untuk mencari nilai dari Contrast, Correlation, Homogeneity dan Energy. Setiap gambar jika diekstraksi akan menghasilkan nilai tersebut. Pada penelitian ini saya menggunakan fungsi yang sudah terdapat pada MATLAB [17]. 


\begin{tabular}{lc}
\hline \multicolumn{1}{c}{ Nama } & \multicolumn{1}{c}{ Persamaan } \\
\hline Contrast & $\sum_{i, j}|i-j|^{2} p(i, j)$ \\
Correlation & $\sum_{i, j} \frac{\left(i-\mu_{i}\right)\left(j-\mu_{j}\right) \vec{p}(i, j)}{\sigma_{i} \sigma_{j}}$ \\
Homogeneity & $\sum_{i, j} \frac{p(i, j)}{1+|i-j|}$ \\
& $\sum_{i, j} p(i, j)^{2}$ \\
\hline
\end{tabular}

Awalnya dilakukan pendeteksian tepi pada gambar menggunakan fungsi, yang terlihat pada persamaan 5:

$B w=e d g e\left(\right.$ gray, ${ }^{\prime}$ canny')

Hasil edge detection akan tersimpan pada variable $B w$, setelah itu dilakukan proses ekstraksi fitur menggunakan fungsi, persamaan 6 .

$G L C M=$ graycoprops $(B w)$

Persamaan tersebut akan menghasilkan suatu nilai berupa matrik yang tersimpan pada array GLCM, untuk mendapatkan nilai dari Contrast, Correlation, Homogeneity dan Energy [17]. Digunakan persamaan yang terlihat pada persamaan 7, 8, 9 dan 10 .

Contrast $=[\operatorname{GLCM}(1,1)$. Contrast $]$

Correlation $=[\operatorname{GLCM}(1,1) \cdot$ Correlation $]$

Energy $=[\operatorname{GLCM}(1,1) \cdot$ Energy $]$

Homogeneity $=[\operatorname{GLCM}(1,1) \cdot$ Homogeneity $]$

\subsection{Naive Bayes}

Teorema Bayes dikemukakan oleh seorang pendeta presbyterian Inggris pada tahun 1763 yang bernama Thomas Bayes. Teorema Bayes ini kemudian disepurnakan oleh Laplace [18]. Nä̈ve Bayes Classifier merupakan sebuah metode klasifikasi yang berakar pada teorema Bayes. Klasifikasi Naive Bayes merupakan bentuk klasifikasi yang melakukan teknik pengklasifikasian dengan menghitung derajat kecocokan dengan cara membandingkan nilai Posterior untuk masing - masing class, dan mengambil class dengan nilai Posterior yang tinggi [19].

Pada penelitian ini metode Naive Bayes digunakan untuk melakukan klasifikasi data, pengklasifikasian dilakukan dengan menggunakan suatu fungsi yang terdapat pada MATLAB yaitu, fungsi fitNaiveBayes. Contoh penggunaan fitNaiveBayes pada MATLAB dapat dilihat pada persamaan 11: 
Dimana pada persamaan 11 tersebut, nilai $X$ merupakan data sampel dan nilai $Y$ merupakan jenis obat, NBModel berfungsi untuk mengembalikan klasifikasi model, dilatih oleh predictor $X$ (data sampel) dan kelas label $Y$ (jenis obat) untuk klasifikasi tingkat $K$. NBModel memprediksi label untuk data baru dengan melewati data.

Sebelum menggunakan fungsi fitNaiveBayes, harus didapatkan data test atau training terlebih dahulu. Data yang digunakan adalah data training yang telah diubah menjadi data angka dalam bentuk Contrast, Correlation, Energy dan Homogeneity seperti dalam persamaan 12. semua data tersebut akan tersimpan ke dalam array data test, dimana data test merupakan suatu array berupa matrik [17].

DataTest $=[$ NCont, NCorr, NEner, NHomg]

Setelah didapatkan nilai dari NBModel dan Data Test selanjutnya dilakukan proses prediksi hasil klasifikasi, menggunakan funsi predict persamaan 13.

PrediksiKelas $=$ NBModel.predict $($ DataTest $)$

Dengan menggunakan fungsi predict maka nantinya akan didapatkan hasil berupa nilai dari jenis kelas, tergolong ke dalam kelas manakah data test yang diklasifikasi tersebut.

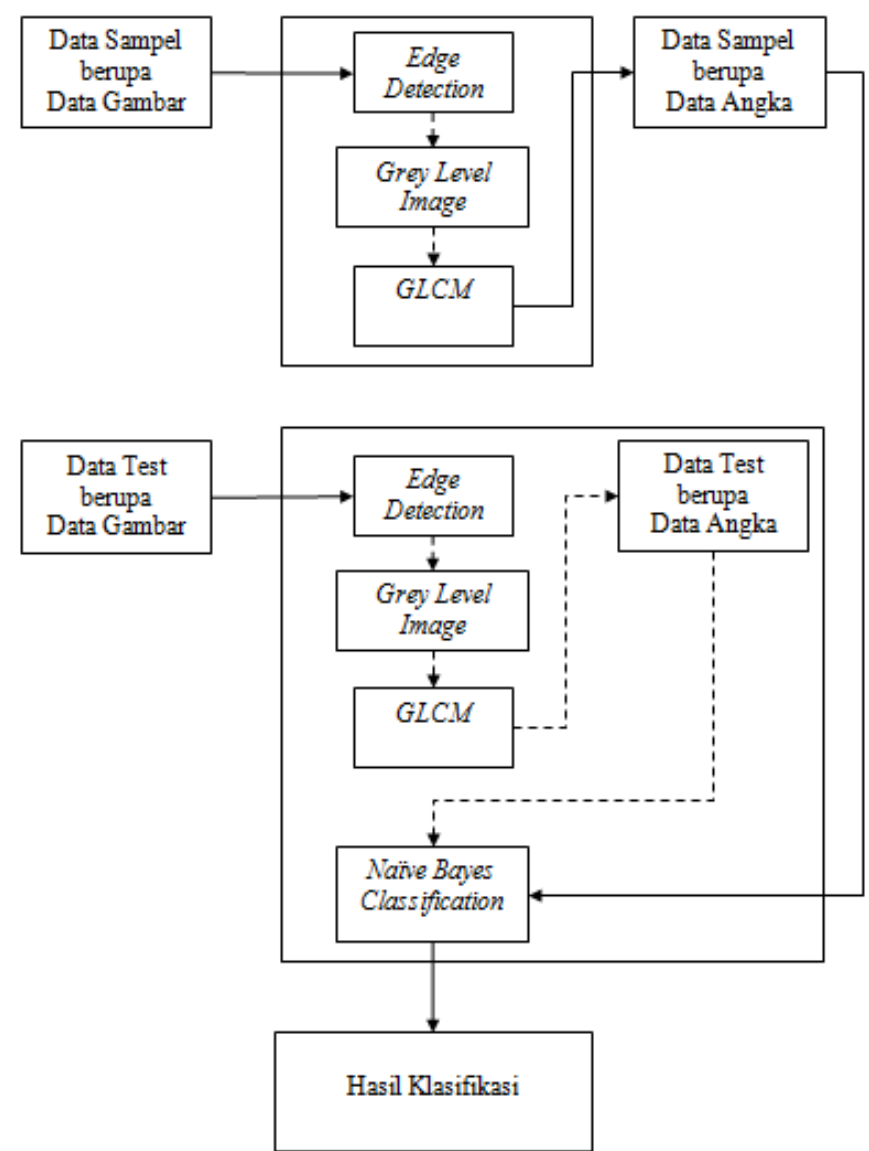

Gambar 1. Alur data, proses ekstraksi dan klasifikasi 


\section{Metodologi}

Alur penelitian yang akan dilakukan adalah:

1) Mengumpulkan data gambar logo, data ini akan digunakan sebagai data test dan data sample.

2) Melakukan deteksi tepi dengan menggunakan metode Edge Detection.

3) Melakukan ekstraksi fitur menggunakan metode GLCM dengan function Greycocrops.

4) Menyimpan data hasil ekstraksi.

5) Menginputkan data test, dan melakukan klasifikasi data test yang telah diinputkan, termasuk kedalam kelas manakah data test tersebut. Klasifikasi data dilakukan menggunakan metode Naive Bayes.

6) Menghitung akurasi yang didapatkan dari proses klasifikasi yang telah dilakukan.

Hal pertama yang dilakukan adalah mengumpulkan data gambar, kemudian memotong gambar, melakukan proses Edge Detection dan GLCM menggunakan aplikasi yang telah dibuat untuk mendapatkan data sample berupa angka. Kemudian selanjutnya dilakukan hal yang sama pada data training menggunakan aplikasi MATLAB. Setelah itu data training yang sudah menjadi angka dibandingkan dengan data sample angka menggunakan metode klasifikasi Nä̈ve Bayes. Semua proses yang dilakukan dapat dilihat pada Gambar 1.

\section{Hasil dan Pembahasan}

\subsection{Menentukan Kelas Berdasarkan Logo Obat}

Penentuan jenis dan banyak kelas ditentukan berdasarkan jenis obat yang telah ditetapkan. Gambar 2 menunjukkan terdapat sebanyak 4 macam obat modern dan 3 macam obat tradisional yang akan saya gunakan, sehingga total akan terdapat 7 macam kelas yang akan digunakan pada proses klasifikasi.

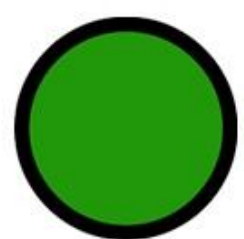

Obat Bebas

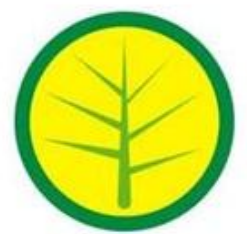

$\mathrm{Jamu}$

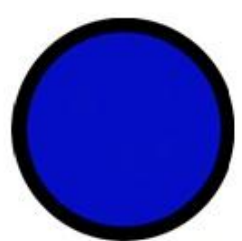

Obat Bebas Terbatas

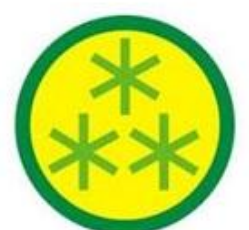

Obat Herbal

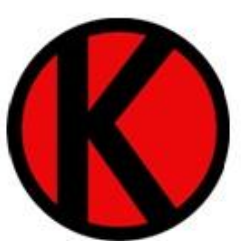

Obat Keras

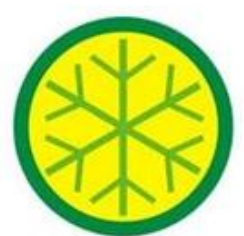

Fitofarmaka

Gambar 2. Jenis Kelas Logo Obat

\subsection{Penjelasan Data Logo Obat}

Terdapat berbagai macam jenis obat yang ada saat ini dan telah tersebar dipasaran, pada penelitian ini saya akan menggunakan jenis obat modern dan jenis obat tradisional. Terdapat sebanyak 4 macam obat modern dan 3 macam obat tradisional yang akan saya gunakan, sehingga total akan terdapat 7 macam jenis logo 
obat yang akan digunakan pada penelitian ini. Obat modern dapat dibagi menjadi 4 golongan [5] [20] (Permenkes No. 725a/1989) yaitu:

\subsubsection{Obat Bebas}

Obat bebas adalah obat yang dijual bebas di pasaran dan dapat dibeli tanpa resep dokter. Gambar 3 menunjukkan tanda khusus pada kemasan sedangkan etiket obat bebas adalah lingkaran hijau dengan garis tepi berwarna hitam. Contoh obat jenis ini adalah Parasetamol dan Multivitamin.

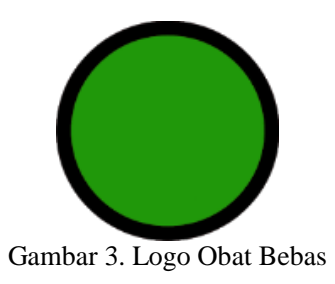

\subsubsection{Obat Bebas Terbatas}

Obat bebas terbatas adalah obat yang sebenarnya termasuk obat keras tetapi masih dapat dijual atau dibeli bebas tanpa resep dokter, dan disertaidengan tanda peringatan. Gambar 4 menunjukkan tanda khusus pada kemasan sedangkan etiket obat bebas terbatas adalah lingkaran biru dengan garis tepi berwarna hitam. Contoh obat jenis ini adalah CTM, Antimo, Noza.

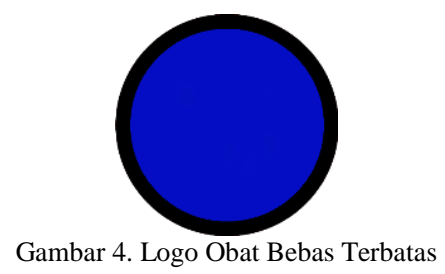

\subsubsection{Obat Keras dan Psikotropika}

Obat keras adalah obat yang hanya dapat dibeli di apotek dengan resep dokter. Gambar 5. Menunjukkan tanda khusus pada kemasan dan etiket adalah huruf $\mathrm{K}$ dalam lingkaran merah dengan garis tepi berwarna hitam [20].

Obat psikotropika adalah obat keras baik alamiah maupun sintetis bukan narkotik, yang berkhasiat psikoaktif melalui pengaruh selektif pada susunan saraf pusat yang menyebabkan perubahan khas pada aktivitas mental dan perilaku [5]. Contoh obat jenis ini adalah Asam Mefenamat, Diazepam, Phenobarbital, Antibiotik (Amoksilin, Klorampenikol), Obat Hipertensi (Hidroklortiazid, Kaptopril).

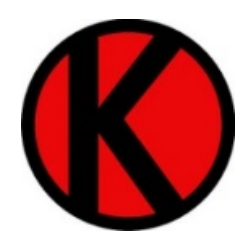

Gambar 5. Logo Obat Keras dan Psikotropika 


\subsubsection{Obat Narkotika}

Obat narkotika adalah obat yang berasal dari tanaman atau bukan tanaman baik sintetis maupun semi sintetis yang dapat menyebabkan penurunan atau perubahan kesadaran, hilangnya rasa, mengurangi sampai menghilangkan rasa nyeri dan menimbulkan ketergantungan [20] [5]. Logo narkotika dapat dilihat pada Gambar 6. Contoh obat jenis ini adaah Morfin dan Petidin.

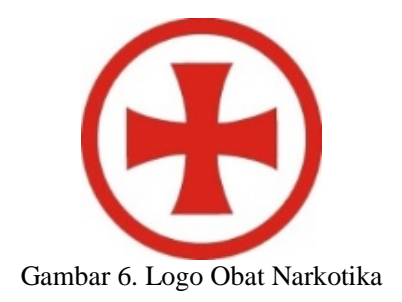

Obat tradisional dibagi menjadi 3 golongan [1] (Keputusan Kepala BPOM Republik Indonesia Nomor: HK.00.05.4.2411), yaitu:

\subsubsection{Jamu}

Jamu adalah ramuan atau obat alami yang digunakan dalam pengobatan untuk menjaga kesehatan, khasiatnya berdasarkan warisan turun temurun. Pihak BPOM telah mengeluarkan standar untuk produksi obat tradisional yang dikenal dengan Cara Pembuatan Obat Tradisional yang Baik (CPOTB). Logo jamu dapat dilihat pada Gambar 7. Contoh obat jenis ini adalah Tolak Angin, Pil Binari, Curmaxan dan Diacinn.

\subsubsection{Obat Herbal Terstandar}

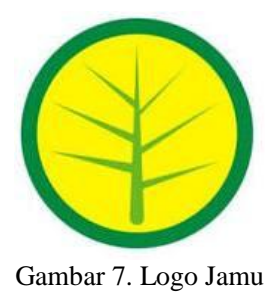

Obat Herbal Terstandar adalah sediaan obat herbal berbahan baku alami, bahan bakunya telah ada pembuktian keamanan dan khasiatnya secara alamiah dengan uji praklinik. Logo obat herbal dapat dilihat pada Gambar 8. Contoh obat jenis ini adalah Fitolac dan Kiranti Sehat.

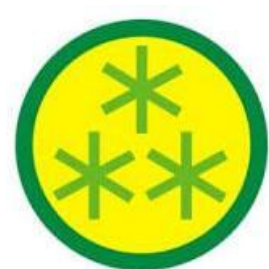

Gambar 8. Logo Obat Herbal Terstandar 


\subsubsection{Fitofarmaka}

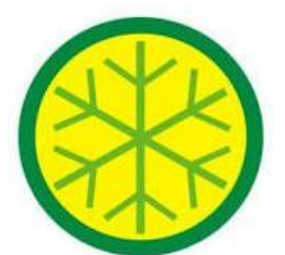

Gambar 9. Contoh Logo Fitofarmaka

Fitofarmaka adalah obat tradisional dari bahan alami yang dapat disetarakan dengan obat modern karena proses pembuatannya yang telah terstandar serta telah ditunjang dengan bukti ilmiah sampai dengan uji klinik pada manusia dengan criteria memenuhi syarat ilmiah. Logo fitofarmaka dapat dilihat pada Gambar 9. Contoh obat jenis ini adalah Nodiar, Rheumaneer, Stimuno, Tensigard, X-Gra.

\subsection{Menentukan Data Sample}

Data sample yang digunakan adalah berupa potongan gambar logo dari beberapa kemasan obat, pemotongan gambar logo dilakukan menggunakan aplikasi GUI Matlab, pada aplikasi ini selain pemotongan juga dilakukan proses Edge Detection dan GLCM. Data yang digunakan adalah sebanyak 10 gambar dari masing - masing jenis obat, sehingga akan terdapat sebanyak 70 buah data sampel yang akan digunakan.

Klasifikasi dilakukan dengan cara memotong logo pada gambar obat, kemudian potongan gambar tersebut ditampilkan pada axe ke 2 dan diperbesar, potongan gambar ini selanjutnya diubah menjadi grayscale dan dideteksi tepi gambar tersebut menggunakan metode Edge Detection, hasil dari proses Edge Detection kemudian diektraksi menggunakan metode GLCM. Hasil dari proses GLCM akan menghasilkan data angka seperti Contrast, Correlation, Energy dan Homogeneity. Data ini kemudian disimpan untuk nantinya digunakan sebagai pembanding dalam proses klasifikasi menggunakan metode Nä̈ve Bayes. Berikut adalah data sample yang dihasilkan dari proses pemotongan, Edge Detection dan GLCM:

Tabel 3. Data Sample Hasil Ekstraksi GLCM

\begin{tabular}{cccccc}
\hline No & Jenis Obat & Contrast & Correlation & Energy & Homogeneity \\
\hline 1 & Bebas & $1.49 \mathrm{E}+02$ & $8.23 \mathrm{E}-02$ & $1.18 \mathrm{E}-02$ & $2.00 \mathrm{E}-01$ \\
2 & Bebas & $6.47 \mathrm{E}+01$ & $2.50 \mathrm{E}-01$ & $1.54 \mathrm{E}-02$ & $2.27 \mathrm{E}-01$ \\
3 & $3.73 \mathrm{E}+02$ & $-2.10 \mathrm{E}-01$ & $7.41 \mathrm{E}-03$ & $1.05 \mathrm{E}-01$ \\
4 & Bebas & $3.07 \mathrm{E}+02$ & $-3.25 \mathrm{E}-01$ & $9.17 \mathrm{E}-03$ & $1.19 \mathrm{E}-01$ \\
5 & Bebas & $3.15 \mathrm{E}+02$ & $-3.33 \mathrm{E}-01$ & $9.80 \mathrm{E}-03$ & $1.22 \mathrm{E}-01$ \\
6 & Bebas & $2.05 \mathrm{E}+02$ & $-1.13 \mathrm{E}-01$ & $1.18 \mathrm{E}-02$ & $1.44 \mathrm{E}-01$ \\
7 & Bebas & $3.35 \mathrm{E}+02$ & $2.35 \mathrm{E}-01$ & $4.31 \mathrm{E}-03$ & $1.33 \mathrm{E}-01$ \\
8 & Bebas & $1.93 \mathrm{E}+02$ & $-6.99 \mathrm{E}-02$ & $1.18 \mathrm{E}-02$ & $1.28 \mathrm{E}-01$ \\
\hline
\end{tabular}


IGede Surya Rahayuda / Jurnal Sisfo Vol. 06 No. 01 (2016) 17-36

\begin{tabular}{|c|c|c|c|c|c|}
\hline No & Jenis Obat & Contrast & Correlation & Energy & Homogeneity \\
\hline 9 & Bebas & $3.25 \mathrm{E}+02$ & $-3.74 \mathrm{E}-01$ & $1.12 \mathrm{E}-02$ & $1.24 \mathrm{E}-01$ \\
\hline 10 & Bebas & $2.07 \mathrm{E}+02$ & $-2.79 \mathrm{E}-01$ & $1.17 \mathrm{E}-02$ & $1.19 \mathrm{E}-01$ \\
\hline 11 & Bebas Terbatas & $8.87 \mathrm{E}+01$ & 1.75E-01 & $6.94 \mathrm{E}-03$ & 2.06E-01 \\
\hline 12 & Bebas Terbatas & $1.29 \mathrm{E}+02$ & $8.70 \mathrm{E}-03$ & $6.41 \mathrm{E}-03$ & $1.50 \mathrm{E}-01$ \\
\hline 13 & Bebas Terbatas & $2.29 \mathrm{E}+02$ & $-7.35 \mathrm{E}-02$ & 8.93E-03 & $1.09 \mathrm{E}-01$ \\
\hline 14 & Bebas Terbatas & $1.43 \mathrm{E}+02$ & $-3.57 \mathrm{E}-01$ & $1.49 \mathrm{E}-02$ & $1.46 \mathrm{E}-01$ \\
\hline 15 & Bebas Terbatas & $1.33 \mathrm{E}+02$ & $-1.46 \mathrm{E}-01$ & $1.32 \mathrm{E}-02$ & $1.69 \mathrm{E}-01$ \\
\hline 16 & Bebas Terbatas & $1.20 \mathrm{E}+02$ & $-3.62 \mathrm{E}-02$ & $6.90 \mathrm{E}-03$ & $1.56 \mathrm{E}-01$ \\
\hline 17 & Bebas Terbatas & $8.64 \mathrm{E}+01$ & $1.71 \mathrm{E}-01$ & $6.85 \mathrm{E}-03$ & 2.03E-01 \\
\hline 18 & Bebas Terbatas & $1.28 \mathrm{E}+02$ & $1.37 \mathrm{E}-01$ & $6.90 \mathrm{E}-03$ & $1.95 \mathrm{E}-01$ \\
\hline 19 & Bebas Terbatas & $9.10 \mathrm{E}+01$ & $1.02 \mathrm{E}-01$ & $6.94 \mathrm{E}-03$ & $1.86 \mathrm{E}-01$ \\
\hline 20 & Bebas Terbatas & $9.33 \mathrm{E}+01$ & $6.83 \mathrm{E}-02$ & $6.99 \mathrm{E}-03$ & $1.78 \mathrm{E}-01$ \\
\hline 21 & Keras & $3.23 \mathrm{E}+02$ & $-7.03 \mathrm{E}-02$ & 4.46E-03 & $1.12 \mathrm{E}-01$ \\
\hline 22 & Keras & $3.20 \mathrm{E}+02$ & $-8.93 \mathrm{E}-03$ & 4.46E- 03 & $1.28 \mathrm{E}-01$ \\
\hline 23 & Keras & $3.04 \mathrm{E}+02$ & $-4.65 \mathrm{E}-02$ & $4.08 \mathrm{E}-03$ & $1.28 \mathrm{E}-01$ \\
\hline 24 & Keras & $2.29 \mathrm{E}+02$ & $-1.18 \mathrm{E}-01$ & $3.37 \mathrm{E}-03$ & $1.51 \mathrm{E}-01$ \\
\hline 25 & Keras & $3.32 \mathrm{E}+02$ & $-1.63 \mathrm{E}-01$ & $3.95 \mathrm{E}-03$ & $1.33 \mathrm{E}-01$ \\
\hline 26 & Keras & $3.56 \mathrm{E}+02$ & $-1.03 \mathrm{E}-01$ & $4.17 \mathrm{E}-03$ & $1.35 \mathrm{E}-01$ \\
\hline 27 & Keras & $3.05 \mathrm{E}+02$ & $5.67 \mathrm{E}-02$ & $4.17 \mathrm{E}-03$ & $1.26 \mathrm{E}-01$ \\
\hline 28 & Keras & $2.69 \mathrm{E}+02$ & $6.61 \mathrm{E}-02$ & $4.17 \mathrm{E}-03$ & $1.45 \mathrm{E}-01$ \\
\hline 29 & Keras & $3.47 \mathrm{E}+02$ & $-2.11 \mathrm{E}-01$ & $4.46 \mathrm{E}-03$ & $1.32 \mathrm{E}-01$ \\
\hline 30 & Keras & $3.29 \mathrm{E}+02$ & $-1.57 \mathrm{E}-01$ & $4.46 \mathrm{E}-03$ & $1.29 \mathrm{E}-01$ \\
\hline 31 & Narkotika & $5.18 \mathrm{E}+02$ & $-1.41 \mathrm{E}-02$ & $2.19 \mathrm{E}-03$ & 1.19E-01 \\
\hline
\end{tabular}


IGede Surya Rahayuda / Jurnal Sisfo Vol. 06 No. 01 (2016) 17-36

\begin{tabular}{|c|c|c|c|c|c|}
\hline No & Jenis Obat & Contrast & Correlation & Energy & Homogeneity \\
\hline 32 & Narkotika & $1.33 \mathrm{E}+02$ & 3.32E-02 & $6.41 \mathrm{E}-03$ & $1.84 \mathrm{E}-01$ \\
\hline 33 & Narkotika & $2.47 \mathrm{E}+02$ & $-8.80 \mathrm{E}-02$ & $3.56 \mathrm{E}-03$ & 1.45E-01 \\
\hline 34 & Narkotika & $2.68 \mathrm{E}+02$ & $1.70 \mathrm{E}-01$ & 2.73E-03 & $1.47 \mathrm{E}-01$ \\
\hline 35 & Narkotika & $1.12 \mathrm{E}+02$ & 2.69E-01 & $5.85 \mathrm{E}-03$ & $1.76 \mathrm{E}-01$ \\
\hline 36 & Narkotika & $5.43 \mathrm{E}+02$ & $-1.44 \mathrm{E}-01$ & $2.19 \mathrm{E}-03$ & $1.16 \mathrm{E}-01$ \\
\hline 37 & Narkotika & $5.04 \mathrm{E}+02$ & $-3.20 \mathrm{E}-02$ & $2.19 \mathrm{E}-03$ & $1.14 \mathrm{E}-01$ \\
\hline 38 & Narkotika & $4.99 \mathrm{E}+02$ & $3.91 \mathrm{E}-03$ & $2.19 \mathrm{E}-03$ & $1.22 \mathrm{E}-01$ \\
\hline 39 & Narkotika & $3.27 \mathrm{E}+02$ & $-8.08 \mathrm{E}-02$ & $2.83 \mathrm{E}-03$ & $1.37 \mathrm{E}-01$ \\
\hline 40 & Narkotika & $3.26 \mathrm{E}+02$ & $-1.89 \mathrm{E}-01$ & $2.73 \mathrm{E}-03$ & $8.61 \mathrm{E}-02$ \\
\hline 41 & Jamu & $1.81 \mathrm{E}+02$ & $2.36 \mathrm{E}-02$ & $2.89 \mathrm{E}-03$ & $1.53 \mathrm{E}-01$ \\
\hline 42 & Jamu & $1.31 \mathrm{E}+02$ & $1.05 \mathrm{E}-01$ & $6.17 \mathrm{E}-03$ & $1.66 \mathrm{E}-01$ \\
\hline 43 & Jamu & $1.02 \mathrm{E}+02$ & 4.97E-02 & $4.93 \mathrm{E}-03$ & $1.81 \mathrm{E}-01$ \\
\hline 44 & Jamu & $4.12 \mathrm{E}+02$ & 2.77E-02 & $1.98 \mathrm{E}-03$ & $1.16 \mathrm{E}-01$ \\
\hline 45 & Jamu & $1.82 \mathrm{E}+02$ & $-2.88 \mathrm{E}-01$ & $5.56 \mathrm{E}-03$ & $1.63 \mathrm{E}-01$ \\
\hline 46 & Jamu & $3.92 \mathrm{E}+02$ & $1.57 \mathrm{E}-02$ & $1.79 \mathrm{E}-03$ & $1.22 \mathrm{E}-01$ \\
\hline 47 & Jamu & $5.22 \mathrm{E}+02$ & $-1.06 \mathrm{E}-01$ & $1.82 \mathrm{E}-03$ & $1.19 \mathrm{E}-01$ \\
\hline 48 & Jamu & $5.53 \mathrm{E}+02$ & $-1.75 \mathrm{E}-01$ & $1.82 \mathrm{E}-03$ & $1.13 \mathrm{E}-01$ \\
\hline 49 & Jamu & $5.43 \mathrm{E}+02$ & $-1.48 \mathrm{E}-01$ & $1.79 \mathrm{E}-03$ & $1.07 \mathrm{E}-01$ \\
\hline 50 & Jamu & $3.68 \mathrm{E}+02$ & $1.46 \mathrm{E}-02$ & $1.82 \mathrm{E}-03$ & $1.21 \mathrm{E}-01$ \\
\hline 51 & Herbal & $2.02 \mathrm{E}+02$ & $1.55 \mathrm{E}-01$ & $4.65 \mathrm{E}-03$ & $1.47 \mathrm{E}-01$ \\
\hline 52 & Herbal & $1.19 \mathrm{E}+02$ & $1.83 \mathrm{E}-01$ & $9.90 \mathrm{E}-03$ & $2.02 \mathrm{E}-01$ \\
\hline 53 & Herbal & $1.60 \mathrm{E}+02$ & $1.69 \mathrm{E}-01$ & $4.17 \mathrm{E}-03$ & $1.79 \mathrm{E}-01$ \\
\hline 54 & Herbal & $3.74 \mathrm{E}+02$ & $-3.02 \mathrm{E}-01$ & 4.02E-03 & 7.03E-02 \\
\hline
\end{tabular}


IGede Surya Rahayuda / Jurnal Sisfo Vol. 06 No. 01 (2016) 17-36

\begin{tabular}{|c|c|c|c|c|c|}
\hline No & Jenis Obat & Contrast & Correlation & Energy & Homogeneity \\
\hline 55 & Herbal & $1.11 \mathrm{E}+02$ & $1.79 \mathrm{E}-02$ & $5.08 \mathrm{E}-03$ & $1.79 \mathrm{E}-01$ \\
\hline 56 & Herbal & $3.17 \mathrm{E}+02$ & $-1.60 \mathrm{E}-01$ & $4.00 \mathrm{E}-03$ & $1.47 \mathrm{E}-01$ \\
\hline 57 & Herbal & $2.60 \mathrm{E}+02$ & $1.34 \mathrm{E}-01$ & $4.00 \mathrm{E}-03$ & $1.19 \mathrm{E}-01$ \\
\hline 58 & Herbal & $3.34 \mathrm{E}+02$ & $-8.28 \mathrm{E}-02$ & $4.00 \mathrm{E}-03$ & $1.29 \mathrm{E}-01$ \\
\hline 59 & Herbal & $2.28 \mathrm{E}+02$ & $-1.58 \mathrm{E}-02$ & 4.27E-03 & $1.67 \mathrm{E}-01$ \\
\hline 60 & Herbal & $3.74 \mathrm{E}+02$ & $-3.02 \mathrm{E}-01$ & $4.02 \mathrm{E}-03$ & 7.03E-02 \\
\hline 61 & Fitofarmaka & $8.33 \mathrm{E}+01$ & 2.22E-02 & $8.20 \mathrm{E}-03$ & $2.23 \mathrm{E}-01$ \\
\hline 62 & Fitofarmaka & $1.39 \mathrm{E}+02$ & $3.25 \mathrm{E}-02$ & $5.75 \mathrm{E}-03$ & $1.87 \mathrm{E}-01$ \\
\hline 63 & Fitofarmaka & $6.83 \mathrm{E}+01$ & $1.50 \mathrm{E}-01$ & $1.04 \mathrm{E}-02$ & $2.25 \mathrm{E}-01$ \\
\hline 64 & Fitofarmaka & $2.32 \mathrm{E}+02$ & 8.92E-02 & $1.05 \mathrm{E}-02$ & $1.31 \mathrm{E}-01$ \\
\hline 65 & Fitofarmaka & $4.60 \mathrm{E}+02$ & $2.12 \mathrm{E}-03$ & $1.47 \mathrm{E}-03$ & $1.18 \mathrm{E}-01$ \\
\hline 66 & Fitofarmaka & $4.35 \mathrm{E}+02$ & $6.91 \mathrm{E}-02$ & $1.47 \mathrm{E}-03$ & $1.22 \mathrm{E}-01$ \\
\hline 67 & Fitofarmaka & $4.81 \mathrm{E}+02$ & $5.59 \mathrm{E}-03$ & $1.52 \mathrm{E}-03$ & $1.12 \mathrm{E}-01$ \\
\hline 68 & Fitofarmaka & $4.35 \mathrm{E}+02$ & $6.91 \mathrm{E}-02$ & $1.47 \mathrm{E}-03$ & $1.22 \mathrm{E}-01$ \\
\hline 69 & Fitofarmaka & $5.01 \mathrm{E}+02$ & $-4.93 \mathrm{E}-02$ & $1.48 \mathrm{E}-03$ & $1.15 \mathrm{E}-01$ \\
\hline 70 & Fitofarmaka & $4.90 \mathrm{E}+02$ & $-1.36 \mathrm{E}-02$ & $1.45 \mathrm{E}-03$ & $1.18 \mathrm{E}-01$ \\
\hline
\end{tabular}

\subsection{Menentukan Data Training}

Setelah proses penyimpanan data sample, langkah selanjutnya yang dilakukan adalah menentukan data training, data training yang akan digunakan adalah sebanyak 35 gambar obat, dimana masing - masing jenis terdapat sebanyak 5 buah gambar obat, Gambar 10, 11, 12, 13, 14, 15 dan Gambar 16. 


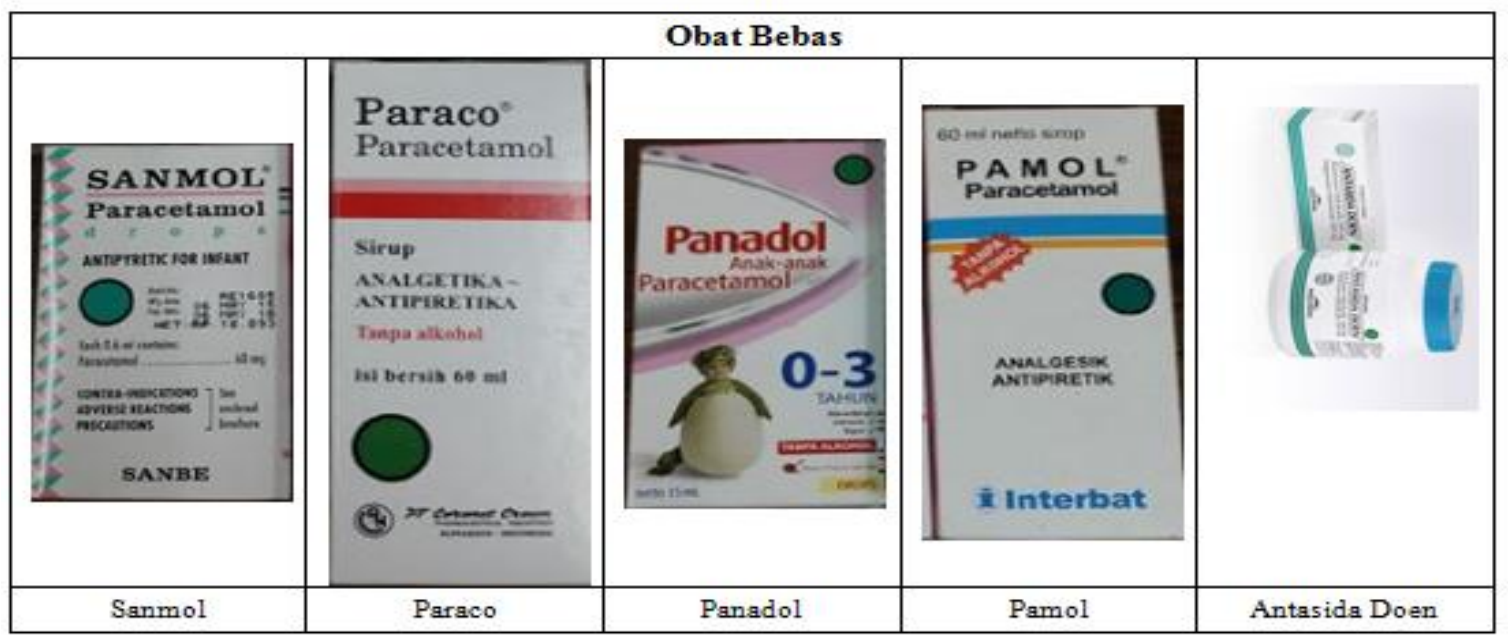

Gambar 10. Data Training Obat Bebas

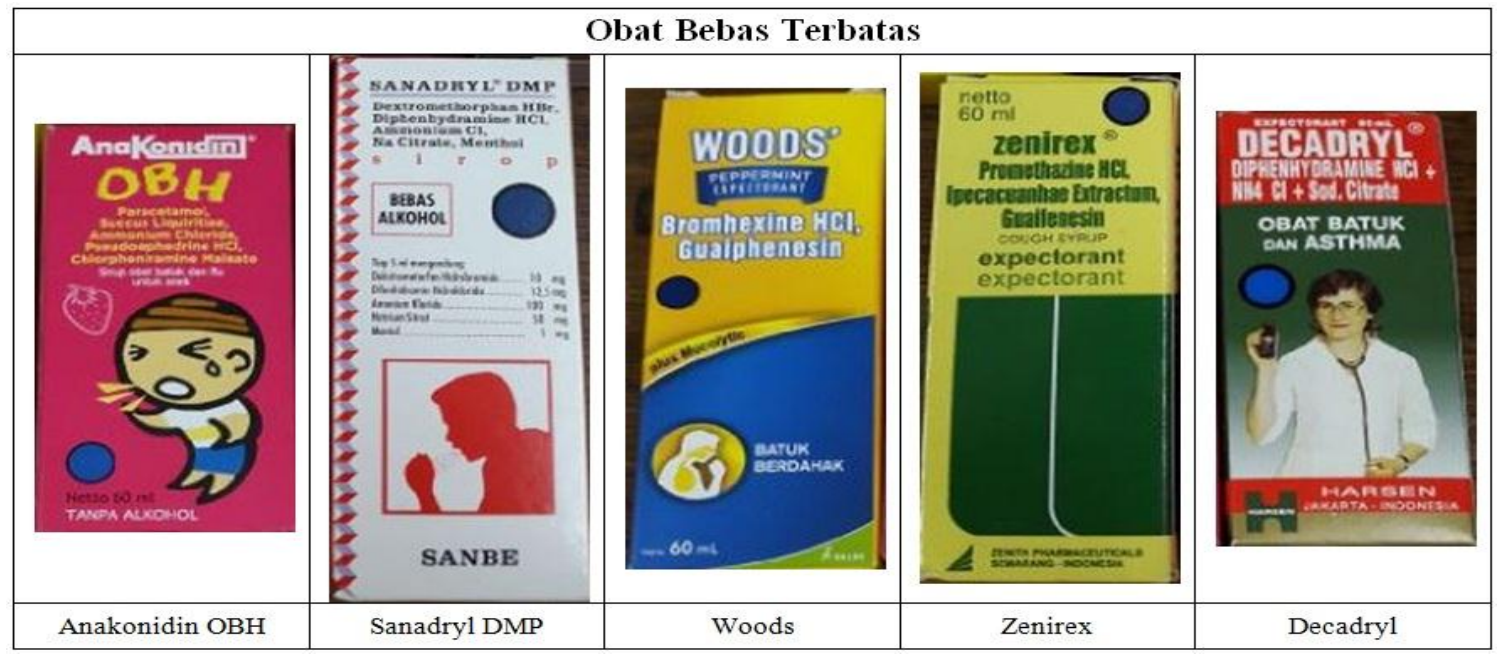

Gambar 11. Data Training Obat Bebas Terbatas

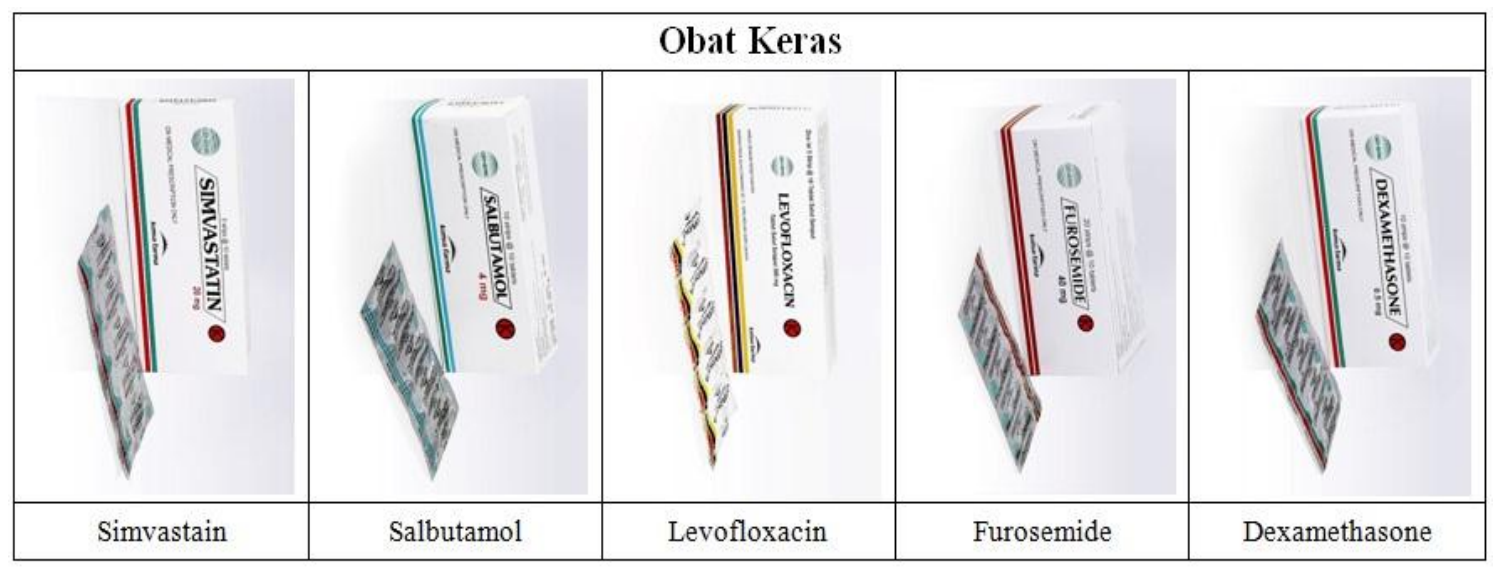

Gambar 12. Data Training Obat Keras 


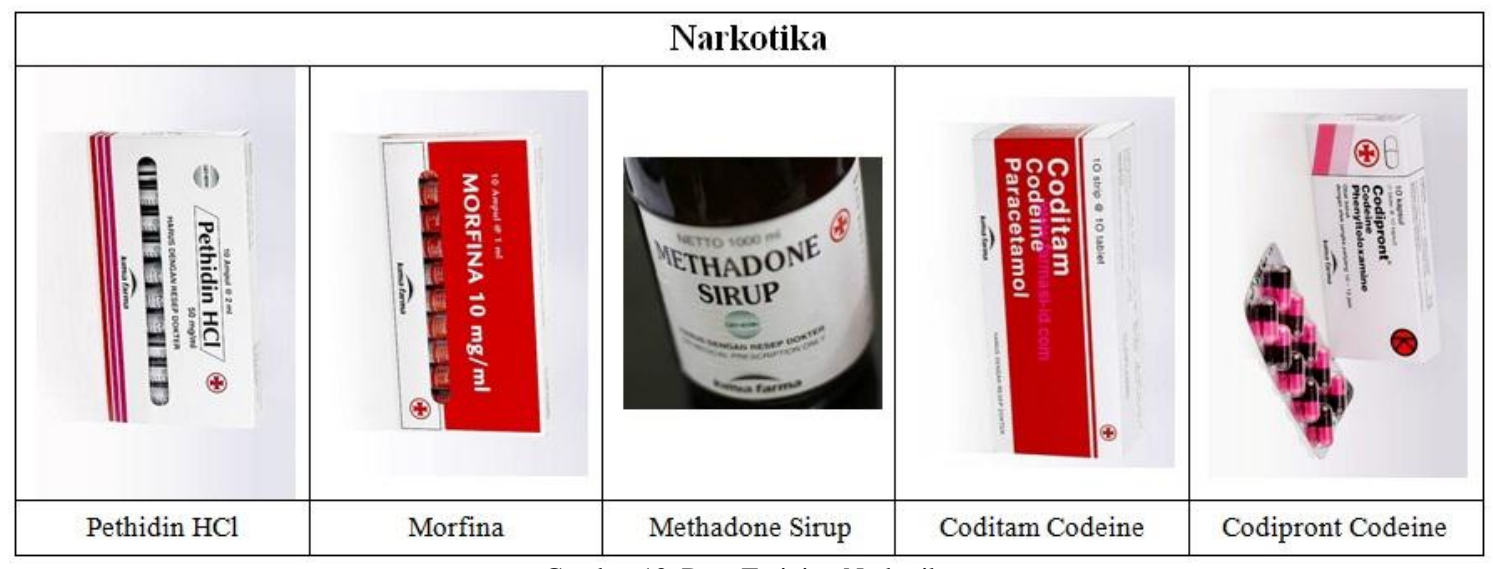

Gambar 13. Data Training Narkotika

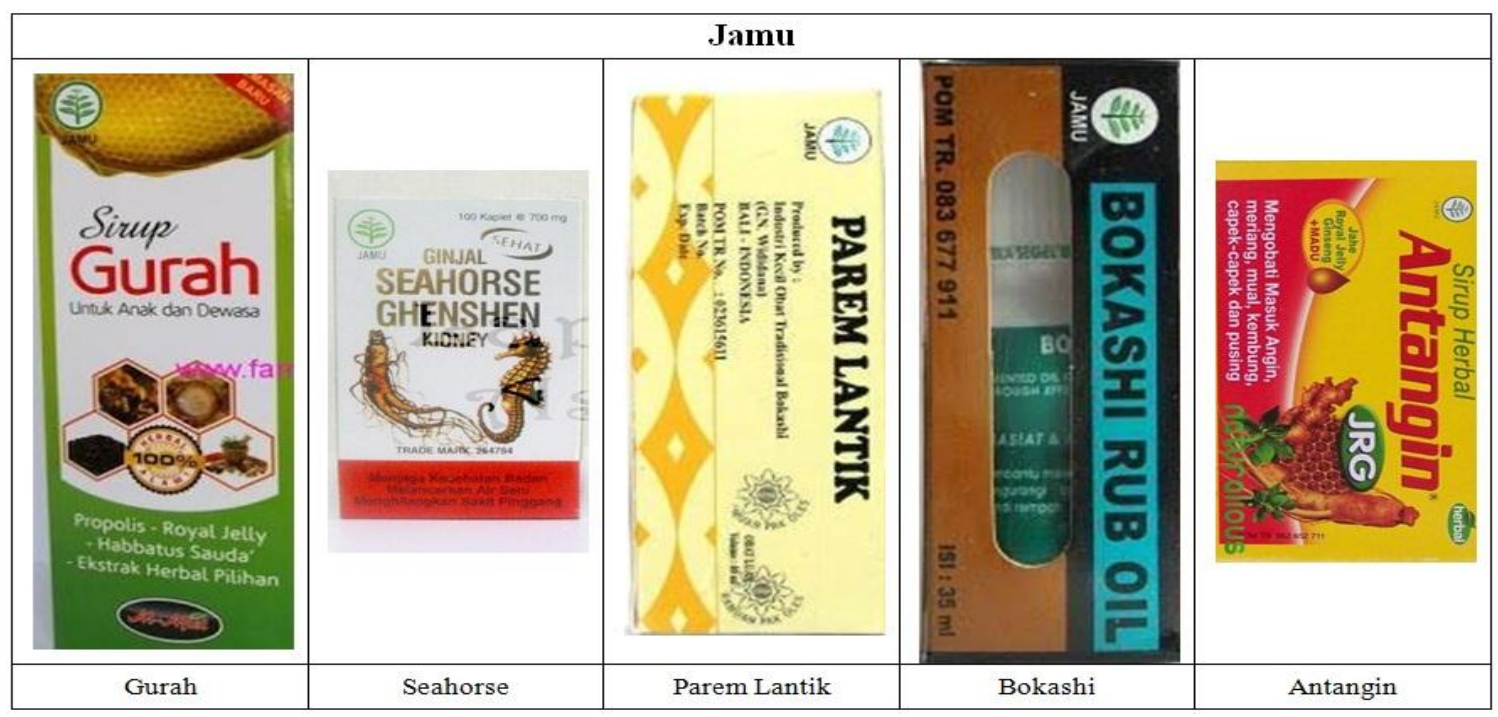

Gambar 14. Data Training Jamu

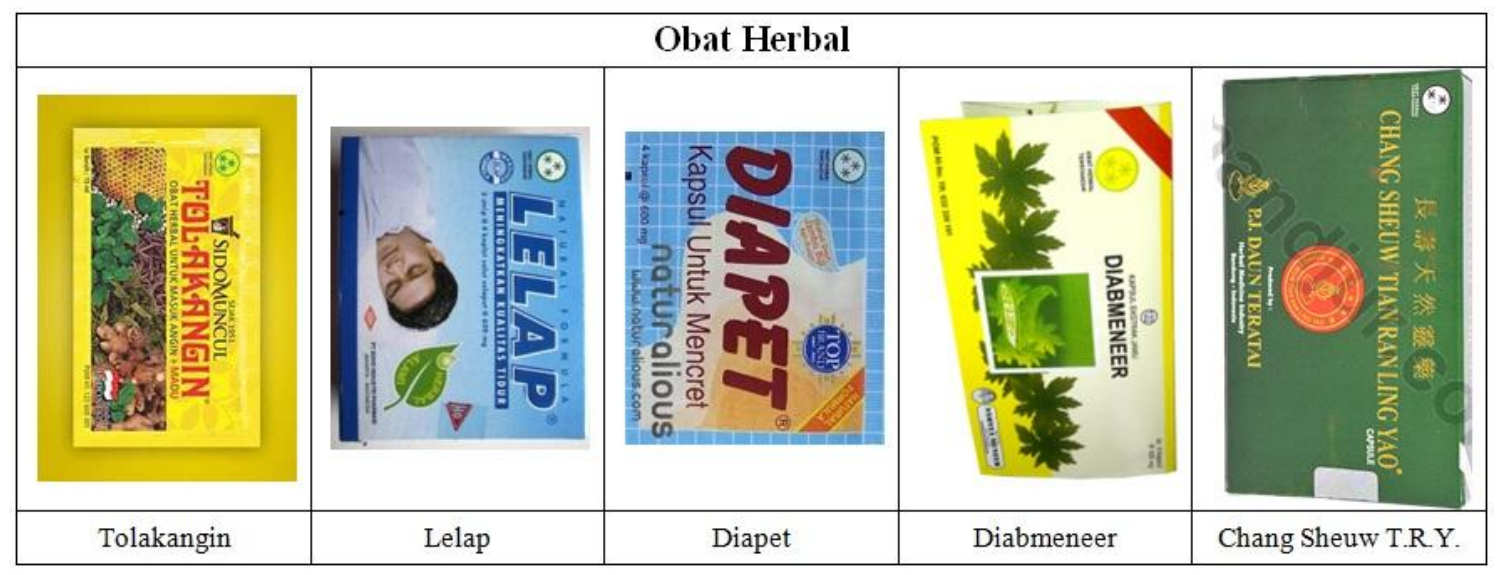

Gambar 15. Data Training Obat Herbal 


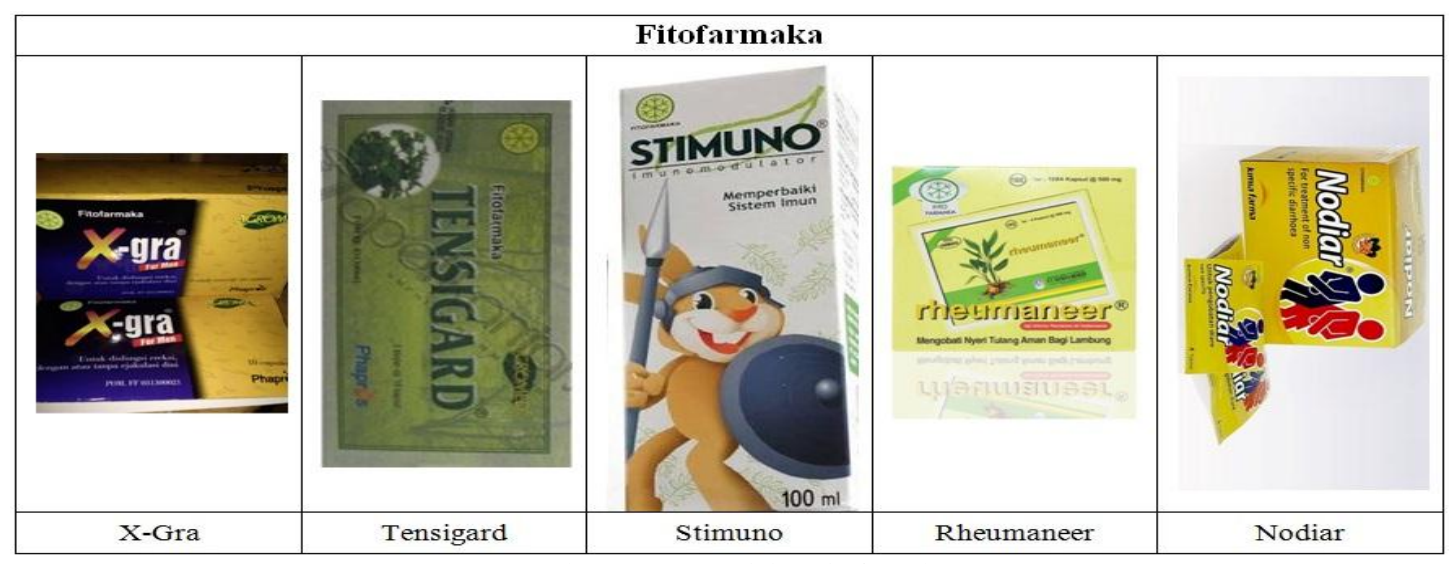

Gambar 16. Data Training Fitofarmaka

\subsection{Hasil Percobaan}

Dari 35 data sample yang telah dikumpulkan, selanjutnya dilakukan proses pemotongan gambar, Edge Detection, GLCM dan klasifikasi Naive Bayes. Semua proses ini dapat dilakukan dalam 1 aplikasi seperti yang terlihat pada Gambar 17, 18 dan 19. Data gambar dipotong, setelah itu diekstraksi dan kemudian diklasifikasi menggunakan metode Naive Bayes.

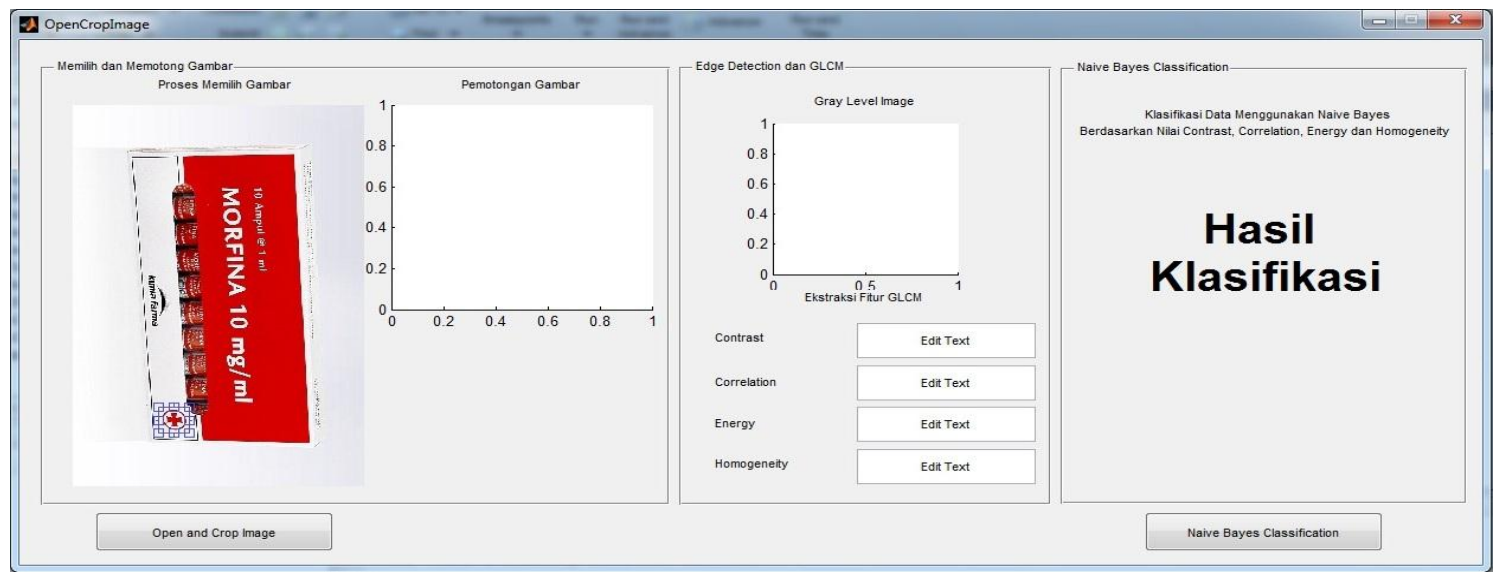

Gambar 17. Proses Pemotongan Gambar

Percobaan yang dilakukan akan menghasilkan data hasil ekstraksi dan data hasil klasifikasi. Data hasil klasifikasi nantinya akan bernilai benar atau salah, jika benar maka akan bernilai 1 dan jika salah akan diberikan nilai 0 . Hasil percobaan ini dicatat pada tabel hasil percobaan. Masing-masing jenis obat terdapat 5 buah data sample. Akurasi atau ketepatan klasifikasi didapatkan dari jumlah nilai benar dibagi dengan jumlah data kemudian dikalikan dengan 100\%. Akurasi juga akan dicatat pada tabel hasil percobaan yaitu Tabel 4 .

Percobaan ini akan memiliki banyak kemungkinan untuk menghasilkan data ekstraksi fitur yang berbeda. Karena pada setiap pemotongan memiliki titik atau sudut potongan yang berbeda. Karena kemungkinan untuk mendapatkan hasil klasifikasi yang benar menjadi lebih susah. Dari hasil percobaan yang dilakukan terhadap beberapa sample didapatkan bahwa beberapa jenis obat memiliki akurasi yang sangat tinggi sebesar $100 \%$ yaitu pada jenis Obat Bebas Terbatas dan Obat Keras. Ketepatan hasil klasifikasi ini 
mungkin terjadi karena bentuk dari logo Obat Keras memiliki bentuk yang unik berupa huruf $\mathrm{K}$ dan jenis logo ini sangat jauh berbeda dengan bentuk logo lainnya.

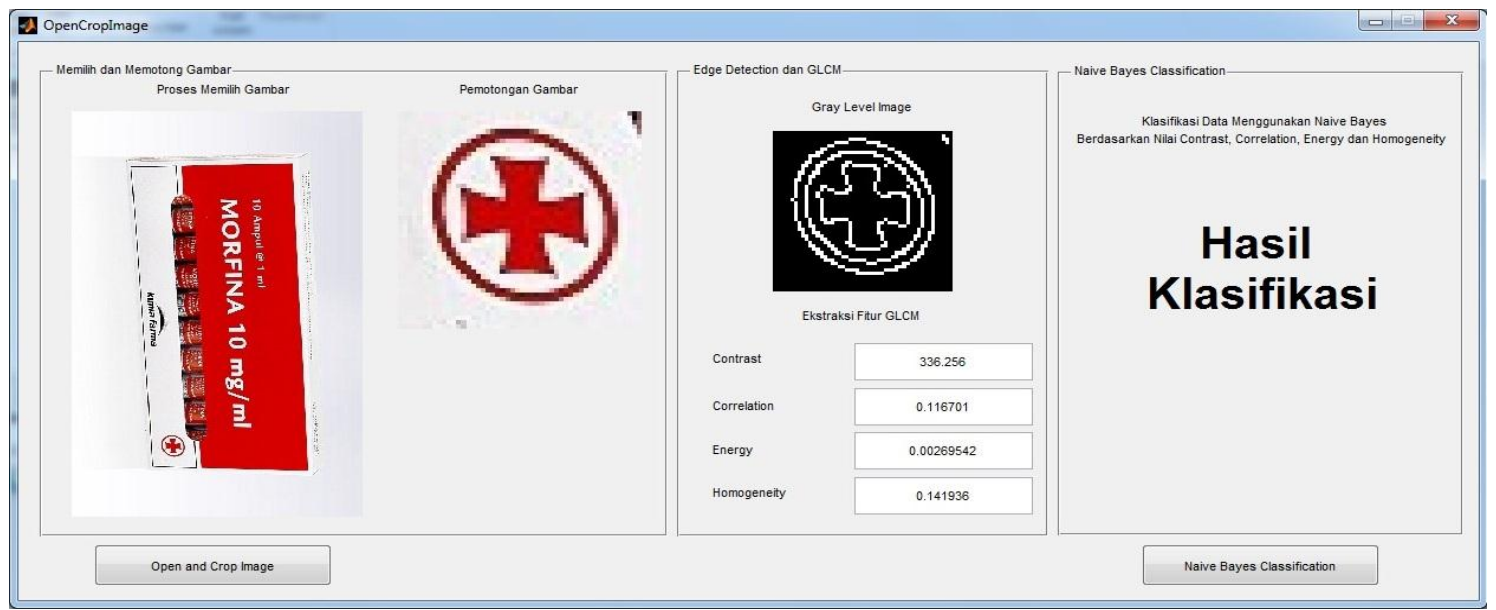

Gambar 18. Proses Edge Detection dan GLCM

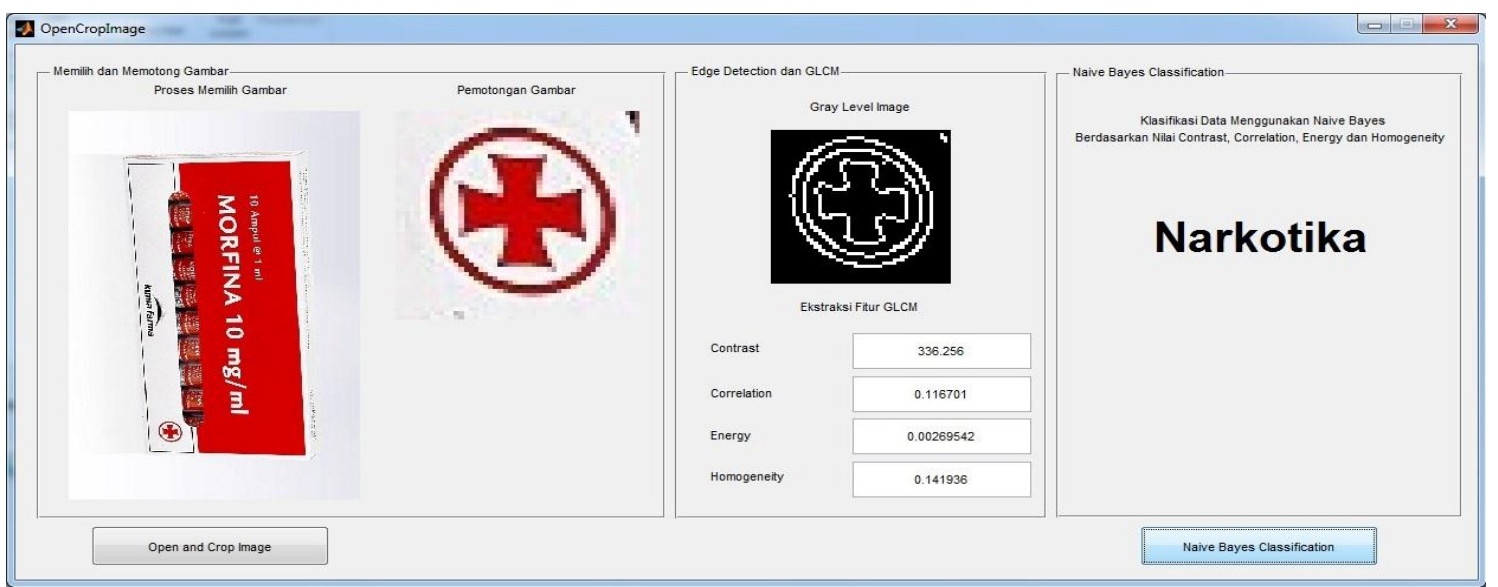

Gambar 19. Proses Klasifikasi dengan Metode Naïve Bayes

Hasil yang tinggi juga terjadi pada jenis Obat Bebas Terbatas, ini mungkin disebabkan karena bentuk dari logo obat yang cukup simple berupa bentuk lingkaran, bentuk ini mudah untuk dibaca oleh aplikasi. Logo dengan bentuk serupa juga terdapat pada jenis logo obat Obat Bebas, hanya saja memiliki warna yang berbeda dengan Obat Bebas Terbatas.

Obat Bebas juga memiliki tingkat akurasi klasifikasi yang tinggi yaitu sebesar $80 \%$, dimana terdapat satu data yang salah diklasifikasi sebgai Obat Bebas Terbatas. Hal ini mungkin saja terjadi karena logo dari Obat Bebas Terbatas dan Obat Bebas memiliki tingkat kemiripan yang tinggi. Selain itu jenis obat lainnya memiliki tingkat akurasi yang sangat kurang, seperti pada jenis Narkotika dengan akurasi sebesar 40\%, jamu sebesar $20 \%$, Obat Herbal sebesar $20 \%$, bahkan ada juga jenis obat yang sama sekali tidak memilii nilai benar pada saat dilakukannya percobaan yaitu pada jenis obat fitofarmaka sebesar $0 \%$. Nilai akurasi yang kecil mungkin disebabkan karena logo yang sangat rumit, amungkin juga terjadi karena gambar data sample yang tidak jelas atau terlalu kecil. Selain itu mungkin juga terjadi karena sudut pengambilan gambar yang berbeda sehingga akan menghasilkan ekstraksi yang berbeda. 


\begin{tabular}{|c|c|c|c|c|}
\hline No & Nama Obat & Hasil Klasifikasi & Benar/Salah & Akurasi \\
\hline 1 & Sanmol & Obat Bebas & 1 & \\
\hline 2 & Paraco & Obat Bebas & 1 & \\
\hline 3 & Panadol & Obat Bebas Terbatas & 0 & $80 \%$ \\
\hline 4 & Pamol & Obat Bebas & 1 & \\
\hline 5 & Paractamol & Obat Bebas & 1 & \\
\hline 6 & Anakonidin $\mathrm{OBH}$ & Obat Bebas Terbatas & 1 & \\
\hline 7 & Sanadryl DMP & Obat Bebas Terbatas & 1 & \\
\hline 8 & Woods & Obat Bebas Terbatas & 1 & $100 \%$ \\
\hline 9 & Zenirex & Obat Bebas Terbatas & 1 & \\
\hline 10 & Decadryl & Obat Bebas Terbatas & 1 & \\
\hline 11 & Simvastain & Obat Keras & 1 & \\
\hline 12 & Salbutamol & Obat Keras & 1 & \\
\hline 13 & Levofloxacin & Obat Keras & 1 & $100 \%$ \\
\hline 14 & Furosemide & Obat Keras & 1 & \\
\hline 15 & Dexamethasone & Obat Keras & 1 & \\
\hline 16 & Pethidin HCL & Obat Bebas Terbatas & 0 & \\
\hline 17 & Morfina & Narkotika & 1 & \\
\hline 18 & Methadone Sirup & Narkotika & 1 & $40 \%$ \\
\hline 19 & Coditam Codeine & Obat Bebas Terbatas & 0 & \\
\hline 20 & Codipront Codeine & Jamu & 0 & \\
\hline \multirow[t]{2}{*}{21} & Gurah & Obat Bebas Terbatas & 0 & \\
\hline & & & & $20 \%$ \\
\hline 22 & Seahorse & Jamu & 1 & \\
\hline
\end{tabular}




\begin{tabular}{|c|c|c|c|c|}
\hline No & Nama Obat & Hasil Klasifikasi & Benar/Salah & Akurasi \\
\hline 23 & Parem Lantik & Obat Bebas Terbatas & 0 & \\
\hline 24 & Bokashi & Obat Herbal & 0 & \\
\hline 25 & Antangin & Narkotika & 0 & \\
\hline 26 & Tolak Angin & Obat Bebas Terbatas & 0 & \\
\hline 27 & Lelap & Obat Herbal & 1 & \\
\hline 28 & Diapet & Obat Bebas Terbatas & 0 & $20 \%$ \\
\hline 29 & Diabmeneer & Obat Bebas Terbatas & 0 & \\
\hline 30 & Chang Sheuw T. R. Y. & Obat Bebas Terbatas & 0 & \\
\hline 31 & X - Gra & Narkotika & 0 & \\
\hline 32 & Tensigard & Obat Bebas Terbatas & 0 & \\
\hline 33 & Stimuno & Obat Bebas Terbatas & 0 & $0 \%$ \\
\hline 34 & Rheumaneer & Jamu & 0 & \\
\hline 35 & Nodiar & Obat Bebas Terbatas & 0 & \\
\hline
\end{tabular}

\section{Kesimpulan dan Saran}

\subsection{Kesimpulan}

Dari percobaan yang telah dilakukan dapat disimpulkan bahwa pada hasil percobaan didapatkan tingkat akurasi yang dihasilkan cukup tinggi, terdapat 3 buah kategori jenis obat yang memiliki akurasi yang tinggi yaitu pada jenis Obat Bebas sebesar 80\%, Obat Bebas Terbatas sebesar 100\% dan Obat Keras sebesar $100 \%$. Akurasi yang cukup tinggi ini mungkin disebabkan karena bentuk logo yang mudah untuk diekstraksi, sehingga menghasilkan hasil ekstraksi yang relative sama dengan beberapa data sample sejenis lainnya.

Dengan hasil yang demikian maka data tersebut akan mudah diklasifikasikan. Beberapa hasil klasifikasi juga menghasilkan hasil akurasi yang kurang tepat, ini mungkin disebabkan karena gambar logo yang terlalu rumit atau gambar yang kurang jelas.

\subsection{Saran}

Beberapa saran untuk kemajuan penelitian yaitu: 
1) Penambahan penggunaan beberapa metode klasifikasi lainnya agar didapatkan suatu perbandingan dan pembelajaran mengenai beberapa metode klasifikasi data.

2) Lebih mengoptimalkan metode klasifikasi Naive Bayes menggunakan fungsi - fungsi baru yang terdapat pada MATLAB.

3) Pemotongan gambar logo secara manual dapat diganti dengan penambahan suatu metode atau sistem yang berguna untuk melakukan pencarian suatu bentuk dalam gambar secara otomatis, seperti metode Face Detection untuk pendeteksian wajah seseorang pada foto sekumpulan orang. Sehingga sistem atau aplikasi seperti ini akan dapat secara otomatis mencari logo tertentu dari sebuah gambar.

4) Penambahan data sampel, sehingga pada saat pengklasifikasian data akan didapatkan hasil yang lebih akurat.

\section{Daftar Pustaka}

[1] Hernani, "Pengembangan Biofarmaka Sebagai Obat Herbal Untuk Kesehatan,” Bul. Teknol. Pascapanen Pertan., vol. 7, no. 1, 2011.

[2] D. M. Sari, “Aplikasi Informasi Obat Bebas Berbasis Android,” STMIK AMIKOM Yogyakarta, 2013.

[3] Ariastuti and Reni, "Profile Swamedikasi dan Hubungan Antara Tingkat Pengetahuan dengn Swamedikasi Nyeri Kepala Pada Masyarakat di Kecamatan Banyudono Kabupaten Boyolali," Universitas Muhammadiyah Surakarta, 2011.

[4] Supriyatna, M. MW, Y. Iskandar, and M. Febriyanti, Prinsip Obat Herbal: Sebuah Pengantar Untuk Fitoterapi. Yogyakarta: Depublish, 2014.

[5] Anggradini and S. Lianti, "Perbedaan Pengetahuan Tentang Obat Sebelum dan Sesudah Pemberian Penyuluhan dengan Leaflet pada Ibu - Ibu Pesucen Kecamatan Petarukan Kabupaten Pemalang,” Universitas Muhammadiyah Surakarta, 2011.

[6] A. Hamzah, "Klasifikasi Teks Dengan Naive Bayes Classifier (NBC) untuk Pengelompokan Teks Berita dan Abstract Akademis,” in Prosiding Seminar Nasional Aplikasi Sains dan Teknologi, 2012, no. 2011, pp. 269-277.

[7] P. Fahzuanta, "Analisis Perbandingan Pendeteksi Garis Tepi pada Citra Digital Antara Metode Edge Linking dan Operator Sobel," Universitas Sumatera Utara, 2011.

[8] C. N. Mahender, "Text Classification And Classifiers: A Survey," Int. J. Artif. Intell. Appl., vol. 3, no. 2, pp. 85-99, 2012.

[9] R. Maini and H. Aggarwal, "Study and comparison of various image edge detection techniques," Int. J. image Process. ( IJIP), vol. 147002, no. 3, pp. 1-12, 2009.

[10] S. R. Dixit* and D. A.Y.Deshmukh, "Realization of Canny Edge Detection Algorithm using FPGA," Int. J. Eng. Sci. Res. Technol., vol. 9655, no. 9, pp. 608-618, 2015.

[11] Inwijayati and P. Bertalya, "Identifikasi Ciri Kain Menggunakan Fitur Tekstur dan Gray Level Difference Method," J. Ilm. Ilmu Komput. Progr. Stud. Sist. Inf., 2014.

[12] P. Berens, “A Matlab Toolbox for Circular Statistics,” J. Stat. Softw., vol. 31, no. 10, 2009.

[13] K. W. Gossage, T. S. Tkaczyk, J. J. Rodriguez, and J. K. Barton, "Texture Analysis of Optical Coherence Tomography Images: Feasibility for Tissue Classification,” J. Biomed. Opt., vol. 8, pp. 570-575, 2003.

[14] H. B. Kekre, S. D. Thepade, A. K. Sarode, and V. Suryawanshi, "Image Retrieval using Texture Features extracted from GLCM, LBG and KPE,” Int. J. Comput. Theory Eng., vol. 2, no. 5, pp. 695-700, 2010.

[15] A. Unnikrishnan and K. Balakrishnan, "Grey Level Co - Occurence Matrices: Generalisation and Some New Features," Int. J. Comput. Sci. Eng. Inf. Technol., vol. 2, no. 2, pp. 151-157, 2012.

[16] N. Zulpe and V. Pawar, "GLCM Textural Features for Brain Tumor Classification,” Int. J. Comput. Sci., vol. 9, no. 3, pp. 354$359,2012$.

[17] I. The MathWorks, "Math Works fitNaive Bayes," $2016 . \quad$ [Online]. Available: www.mathworks.com/help/stats/fitnaivebayes.htm. [Accessed: 20-Jul-2016].

[18] N. Purba, "Peranan Teorema Bayes Dalam Pengambilan Keputusan," Universitas Sumatera Utara, 2010.

[19] O. Nuraeni, "Penerapan Data Mining Untuk Menampilkan Informasi Pertumbuhan Berat Badan Ideal Balita dengan Menggunakan Metode Naive Bayes Classifier,” Gunadarma, 2014.

[20] M. Situmorang, "Gambaran Pengetahuan Mahasiswi Bidan Pendidik D-IV USU Terhadap Obat Generik dan Obat Generik Bermerek," Universitas Sumatera Utara, 2012. 
IGede Surya Rahayuda / Jurnal Sisfo Vol. 06 No. 01 (2016) 17-36

Halaman ini sengaja dikosongkan 